\title{
The Peacebuilding Potential of Technical and Vocational Education and Training Programmes in Post-Conflict Sierra Leone
}

\author{
Rikke van der Veen (first author) \\ Independent Researcher \\ Email: rikkevanderveen@gmail.com \\ Dr. Simone Datzberger (second and corresponding author) \\ Lecturer in Education and International Development \\ UCL Institute of Education| Centre of Education and International Development \\ 20 Bedford Way | London WC1H 0A \\ Email: s.datzberger@ucl.ac.uk
}

\begin{abstract}
In peacebuilding contexts, unemployed youth are frequently perceived as a high risk for the stability of a country while employed youth are seen as carrying an enormous potential for economic growth. This paper applies a social justice framework (4Rs) in analysing a Business Development (BD) programme that was implemented as part of Sierra Leone's Technical and Vocational Education and Training (TVET) strategy to promote entrepreneurship development and reduce unemployment among youth. Despite the BD programme's initial strengths, to recognize youth's heterogeneity with the aim to address some of the root causes of the war, we show how the programme struggled to counter social inequality, unemployment and neopatrimonialism. Sudden decreases in donor funding led to severe modifications of redistribution processes, thereby hampering youth's representation. This raises questions about the design of TVET strategies and BD programmes in post-conflict settings in general. Our paper further showcases how the resurfacing of the root causes of a conflict in the scope of small scheme development programmes, can have far reaching effects on young people's various relationships of trust, if not reconciliation process as a whole.
\end{abstract}


Key words: Business Development programmes; TVET, Peacebuilding; Post-Conflict Sierra Leone 


\section{The Peacebuilding Potential of Technical and Vocational}

\section{Training Programmes in Post-Conflict Sierra Leone}

\section{Introduction}

Opposition party candidate of the Sierra Leone Peoples Party (SLPP) Julius Maada Bio's promise of free education earned him many votes in the 2018 National Elections (Kalangba 2018). However, after 16 years of relative political stability, it still remains to be seen whether and how the education sector will fully recover from the brutal civil war (1991-2002) that vandalised around half of the educational facilities and took a heavy toll on teachers and students performances (Bennell, Harding and Rogers-Wright 2004; Nishimuko 2007). The United Nations Development Programme (UNDP) estimates that currently $70 \%$ of all youth are either underemployed or unemployed.1 This is significant as in post-conflict settings, unemployed youth are generally perceived as a high risk for the stability of a country, while employed youth are seen as carrying an enormous potential for economic growth (Lopes Cardozo, Higgins, and Le Mat 2016, 9). In the hope to improve young people's situation, Technical and Vocational Education and Training (TVET) programmes gained a prominent place in international peacebuilding and development practice and discourse (World bank 2017). This is also reflected in the Sustainable Development Goals (SDGs), which call for universal access to quality TVETs. There is an underlying expectation that wider access to TVET not only leads to a decent workforce or boasts the national economy, but also enhances the security situation in conflict-affected environments. At the same time, TVET programmes have been criticised already since the 1960s as programme outcomes did frequently not match expectations (Middleton in Oketch 2007, 222). Scholars started to question the narrow economic and technical problem framing preceding TVET programmes, highlighting that they 
are often not adjusted to the local labour market, provide insufficient training and ignore the voices of youth during programme development (Batmanglich and Enria 2014; Lopes Cardozo, Higgins, and Le Mat 2016). Others caution that, youth employment programmes tend to raise youth's expectations which are often not met by the outcomes, thereby resulting in disappointment, possibly fuelling new conflict (Lopes Cardozo, Higgins, and Le Mat 2016).

Against this backdrop, we examine how a Business Development (BD) programme (in alignment with Sierra Leone's overall TVET strategy) shapes the agency of heterogenous youth in the peacebuilding process of post-conflict Sierra Leone? The BD programme under our examination was implemented in 2012 as part of the Youth Empowerment and Employment Programme (YEEP), a cooperation between the UNDP, the Ministry of Youth Affairs Sierra Leone (MOYA) and the National Youth Commission (NAYCOM) (Government of Sierra Leone 2013). 2 In the scope of its implementation in 2011-2018, YEEP guided Sierra Leones national youth development processes and aims to unleash youth's potential for national development. At the time we wrote this paper, efforts are also underway to develop a national TVET policy, after failed attempts in 2010 and 2014 (Jalloh 2019). We therefore deliberately examine a BD programme through a peacebuilding lens, as according to the MOYA:

'Many of the pre-conflict conditions that helped fuel young people's participation in the civil war (including exclusion from family life, society, jobs and the decision making processes as well as living under oppressive traditional and cultural systems in the rural areas) still exist' (Ministry of Youth Affairs 2014, 20). 
As also argued by Novelli and Higgins (2017), international efforts to transform Sierra Leone's education system thus far failed to deal with underlying social tensions and did not satisfactorily support the country's peacebuilding process. It is questionable whether globally promoted youth employment programmes (such as TVET strategies in Sierra Leone) address these underlying tensions and positively influence a post-conflict society, or if they rather fuel new conflict by raising unmet expectations from youth?

We first briefly discuss current debates on the potential of youth in nurturing economic growth in peacebuilding processes, followed by an overview of our theoretical approach for this paper - the 4R framework developed by Novelli, Lopes Cardozo, and Smith (2017). We continue to outline our qualitative research methods explaining how we selected relevant actors and youth who either participated in or were excluded from the BD programme. In total 37 semi-structured interviews and 5 FGDs (Focus Group Discussions) inform this paper. The ensuing section focuses on the situation of youth in Sierra Leone with a particular focus on youth's everyday experiences and existing efforts to promote employment via TVET programmes. We then elaborate on a BD programme for youth (as part of the country's TVET strategy) that has been widely implemented by an INGO (International Non-Governmental Organisation) in Sierra Leone. In applying the 4Rs framework, we analyse the peacebuilding potential of the BD programme in post-conflict Sierra Leone, while putting our findings into a wider context.

\section{Youth in peacebuilding processes through the lens of the 4Rs framework}

The prioritization of youth as a potential for economic development in conflict-affected environments dominates popular peacebuilding discourses (Kemper 2005; McEvoy-Levy 2006). Yet critics allege that youth are predominantly embraced as a homogeneous group for 
which narrow and technical solutions are sought that serve a liberal peacebuilding goal and consequently underestimate the differences between youth's needs and expectations (Batmanglich and Enria 2014; Lopes Cardozo, Higgins, and Le Mat 2016; Pruitt 2020). For instance, economically driven educational programmes in conflict-affected areas try to give youth the tools to become productive citizens but might thereby not go beyond their individual potential for peacebuilding (Sayed et al. 2016). Sayed et al. further argue that youth's livelihoods enhancement cannot be separated from youth's social and political agency in peacebuilding processes. In other words, apart from the economic situation of youth, social, cultural and political processes also play a prominent role in youth's lives but are hardly incorporated in educational programmes to contribute to sustainable and long-lasting peacebuilding processes (Ibid).

Besides, youth tend to be excluded from political participation and important decision making processes affecting their social and economic status. This frequently stems from underlying social tensions, such as inter-generational power imbalances or deeply historically rooted traditions and norms to submit to elders and show respect (omitted reference). It was not until recently, that youth's wider participation in peacebuilding processes and developing policies was also recognized at the global level with the aim to develop suitable programmes for local realities (Dunne et al. 2014). The latest UN security resolution on youth, peace and security (2250) which was unanimously adopted in 2015, emphasizes 'the importance of youth as agents of change in the maintenance and promotion of peace a country's transition from conflict to peace. 3

While previous scholarship has engaged in important and insightful analysis of the general role of education in Sierra Leone's peacebuilding process (see: Novelli 2011; Novelli and 
Higgins 2017; Higgins and Novelli 2020; Smith Ellison 2014) or provided a critical engagement with unemployment programmes for conflict-affected youth (Batmanglich and Enria 2014), literature is still scarce when it comes to in-depth case studies of the peacebuilding potential of TVETs - especially in the context of Sierra Leone. In addressing this gap, we make use of the 4Rs framework developed by Novelli, Lopes Cardozo, and Smith $(2017,14)$, which, to our knowledge has not yet been applied in other studies of TVETs for youth in post-conflict environments.

The 4R framework combines dimensions of recognition, redistribution, representation, and reconciliation, in linking Fraser's $(2005 ; 1995)$ work on social justice with the peacebuilding and reconciliation work of Galtung (1976), Lederach (1995; 1997), and others, to explore what sustainable peacebuilding via education might look like in post-conflict environments. The potential of BD programmes in post-conflict Sierra Leone, is approached not only with regard to equal redistribution (such as access, resource allocation or equal opportunities) but also being related to the structural, social and systemic conditions necessary for social and political transformation, as follows Lopes Cardozo, Higgins, and Le Mat $(2016,20)$ :

- 'Redistribution concerns equity and non-discrimination in education access, resources, and outcomes for different groups in society, particularly marginalised and disadvantaged groups.

- Recognition concerns respect for and affirmation of diversity, heterogeneity and identities in education structures, processes, and content, in terms of gender, language, politics, religion, ethnicity, culture, and ability. 
- Representation concerns participation, at all levels of the education system, in governance and decision-making related to the allocation, use, and distribution of human and material resources.

- Reconciliation involves dealing with past events, injustices, the material and psychosocial effects of conflict, as well as developing new relationships of trust'(Ibid).

In addition, Fraser's 3Rs are embraced as dimensions that, if disregarded, nurture conflict, or, as elements that can either positively or negatively shape a country's peacebuilding process. Reconciliation, on the other hand, brings to light the many legacies of a conflict.

Correspondingly, we see and treat all 4Rs as interconnected. In short, the present challenges youth in Sierra Leone encounter cannot be detached from the history of the civil war. Persisting issues of redistribution, representation and recognition challenge Sierra Leone's reconciliation process which is much needed for sustainable positive peace. This can be also reflected in small-scheme programmes, as we show in the ensuing sections of this paper.

As done elsewhere (omitted reference) we refrain from a too deterministic and descriptive application of the framework and instead, will highlight how the 4Rs broadly inter-relate and are reflected within TVET programmes to discuss the wider implications for peacebuilding and education sector interventions in Sierra Leone. We therefore embrace the 4Rs framework as a normative and analytical approach at the same time. In this attempt we seek to capture the political, economic, cultural and social dimensions that influence and surround education programmes and discuss how these dimensions relate to sustainable peacebuilding (Novelli, Lopes Cardozo, and Smith 2017). 


\section{Methods}

Qualitative data was collected by the first author during a two month field research stay in Sierra Leone in 2018. Data for this particular paper was analysed, interpreted and written up by both authors. In the view that we are both in the privileged position of having written this paper as white, western researchers, who have lived and worked in Sierra Leone for extended periods, we deemed it as important to treat Sierra Leone's youth as active agents, who are able to contribute to our analysis with their own voice on the basis of their own experience. At the same time, we are aware that our analysis is not free from the problematic nature of interpretation, recognizing that we bring our own perspectives when examining the data (Ashby 2011). As noted by Kincheloe and McLaren (2000), it is not solely our respondents' experience and viewpoints that are being brought to light but also our own interpretation of their experience. While giving voice as a research method can be emancipatory, we acknowledge and want to emphasize that sadly the researcher often benefits more from the telling than the researched (Ibid).

Field research focused specifically on youth who participated in a BD programme between 2012 and 2017, led by an INGO as part of Sierra Leone's overall TVET strategies. Over the years in total 563 people participated in this particular BD programme. The experiences gathered during FGDs and semi-structured interviews captured the influence of the BD programme on youth's economic, political, and social agency. In addition, relevant youthpolicy documents, reports, research studies, news and media articles were reviewed to understand how the position of youth in post-conflict Sierra Leone is framed at different levels of society.

Data collection included in total 37 semi-structured interviews with actors from the government, international aid agencies, local (public/private) agencies and INGOs 
participating in decision-making and implementing processes surrounding TVET strategies and policy development - as well as youth. In addition, 5 FGDs were held with youth in different formations (30 participants in total). This included youth that won a grant as a part of the BD programme (followed by visits to their respective businesses); youth that did not win a grant, and youth that never participated in the BD programme and were excluded. All BD projects that inform this study are implemented in Newton (near the capital Freetown and the city of Waterloo).

The implementing agency helped to select participants, which was considered to be the culturally most sensitive approach as youth showed great trust towards staff members. A random selection would have also challenged a very friendly and collaborative relationship with the agency. During interviews it was thoroughly explained why and how information shared by the participants will be anonymized and cannot be used against respondents. Moreover, the implementing agency expressed that they were in fact very open to, and looking for feedback, as they hoped to improve their programme.

All participants currently live in the Western Rural District but migrated from all over Sierra Leone, representing the general migration trends from rural to urban areas (Ministry of Youth Affairs 2014). During data collection it was, in collaboration with the implementing agency, ensured that to the extent possible, participants exemplified the heterogeneity of Sierra Leone's youth in terms of ethnicity, religion and place of birth. While their level of education and their socio-economic status varied, all of them face similar hardships as they either have responsibilities within family structures or lost at least one parent or caregiver as a consequence of the war and/or Ebola.

Despite the help of the implementing agency, only 13 out of 44 youth who participated in this study are female. This might be due to the cultural and societal boundaries women in Sierra Leone face, in combination with the fact that the field researcher was a white male. It could 
however also be a coincidence. This study therefore refrains from incorporating gender analysis in the concluding findings. Further research is needed to shed light on the influence of TVET programmes on the peacebuilding agency of young women in post-conflict societies.

Research and data collection was made possible thanks to the close collaboration with the before mentioned INGO whose name we do not want to reveal due to the sensitivity of the research. Our intention is not to shed a bad light on the hard work and programming of this INGO and its partners and donors but rather to point to the complexity of designing and implementing TVET programmes for heterogenous youth in peacebuilding and development processes, thereby stressing why serious political and financial commitment is needed. All information from interviewees and FGDs participants is anonymized. We make use of codes for citations from interviews (I), FGDs (F) and private documents (D). These codes are explained and listed by category and number in Appendix 1 and are referred to throughout the paper. After field research was completed, the first author shared initial findings of his research with the implementing agency in the form of a report and is still in contact with former employees of the INGO.

\section{The situation of youth during and after the war in Sierra Leone}

We understand youth as a heterogenous group which is diverse in terms of ethnic origin, religion, regions, differences in educational levels and job opportunities among youth (Harris 2014). In the sub-Saharan African context, youth is frequently approached as a country's population group that is aged between 15-35 (African Union 2006, 3). It is estimated by the UNDP that currently $70 \%$ of all Sierra Leone's youth are either underemployed or unemployed. Besides, only $42 \%$ of all adults are literate, $60 \%$ of the population continues to live below the national poverty line and life expectancy is only 48 years. 4 
Many scholars agree that youth who actively participated in Sierra Leone's civil war (19912002) aimed to change their marginalised position (Keen 2005; Mitton 2015). While the government failed to provide education and other state services, the few educational and job opportunities available were divided through a neo-patrimonial system (Hanlon 2005, 460) . As pointed out by the Sierra Leone Truth and Reconciliation Commission (2004) many of the root causes of the war continue to persists (see: Cubitt 2011; Peters 2011). For instance, youth continuous disadvantaged position was and still is fortified by weak and corrupt post-conflict governments that became heavily dependent on foreign donors and continued to exploit the countries natural resources without redistributing its wealth (Nishimuko 2009). The inability to deal with the 2014 Ebola outbreak and the 2017 mudslides further exposed Sierra Leone's dependency on international aid in an unsparing way (Novelli and Higgins 2017, 33).

Scholars also see the influence of an internationally guided minimalist security-first agenda and 'liberal peace', as one of the reasons why many pre-war triggers are still present in Sierra Leone (Denney 2011; Novelli 2011; Paris 2004).

As of recent, Julius Maada Bio's new presidency (2018) promised to fight corruption and bring long awaited political, economic and social change. Thus far, IMF (International Monetary Fund) spending caps made it impossible to satisfactorily expand the education sector or raise people's salaries feeding into continued corruption (Hanlon 2005, 461). However, the 2019 government budget now allocates $21 \%$ of the total public spending to the education sector, affirming the new presidents intentions to provide free education (Keili 2018). It remains to be seen, if these new initiatives will indeed substantially improve youth's position in the future. For now, field research revealed that young people's agency continues to be strongly undermined by neopatrimonialism, a failure of the government to rebuild their relationship with youth (i.e. a lack of reconciliation) and provide basic services like educational and job opportunities. 


\title{
"Connectocracy" and "sababu": Young people's perspectives on the importance of neopatrimonialism in Sierra Leone
}

\author{
'What is reality here, Sierra Leone is about connectocracy. You have to be connected or you \\ have money, so either pay your way through or you have something like a strong relationship \\ with people before you can be employed' (F4).
}

The above statement by a young male highlights both the importance of sababu and economic space in Sierra Leone's society. Connectocracy and sababu as part of youth's everyday reality and social structures have its origins in Sierra Leones pre-colonial era. Sababu is described by Enria (2015, 643-644) as:

\footnotetext{
'[...] a useful person able to redistribute resources, including access to employment opportunities, within his or her networks. Inability to enter a sababu's circles was seen as the central cause for their lack of acceptable employment. Being excluded from proper jobs, therefore, meant not only being relegated to precarious livelihoods in the context of Sierra Leone' s political economy. It also implied having been excluded from productive social networks. Not having a job was as much about social marginalisation as it was about economic adversity'.
}

Youth who were interviewed for this study consistently linked sababu to one's social position. It was translated by participants as favourism (F4) or as 'being connected to the system'(F5). One interviewee further described sababu as 'associations' that gained real importance during the war. It simply became a survival mechanism. You had to fear for your life 'if you were not with somebody' (I13). 
Youth also noted that older people are traditionally more respected than young people. Yet, elders were not just defined by age but also in terms of someone's financial status, regardless their age. A young male described the sharp division between the rich and the poor as follows:

'In Sierra Leone, we the youth we are by class' and 'we have some youth who are born rich, they will never mingle with (..) us' (...) 'they are elders, they have money, I do not have money. When he [elder person] said something to me, if I argue maybe he takes me to the police station. They will deal with me, treat me so as for me ... I do not like to argue with elder people’ (F3).

While having a Sababu can be very helpful in Sierra Leone, the relationship between marginalized youth and economically and socially influential people often has an abusive character as there is a lack of rules around sababu (I13). 'Your sababu has the power to keep you out of the police station, or pay your medical bills but could also use influence to put you in jail' (F4). At the same time, gaining sababu or economic capital is difficult for youth who lack social and financial guidance, aggravated due to the war and Ebola (I13). When a person has some economic capital, he or she is less vulnerable and less dependent on a sababu for basic survival or favours on different levels. It is however tiresome to gain economic independence without a sababu in Sierra Leone as job opportunities are scarce and divided through a patrimonial system.

\section{Youth's relationship with the government}

According to a leading CSO (Civil Society Organisation) actor working on governance, human rights and legal reform issues, youth created a growing shadow state in that: 
'They do not care what the government does as they are now despondent about government deliverability of basic services so they create their own world'. [There are] 'two competing states: the formal and the informal and then interactions will be difficult'. (...) 'They [youth] are not interacting with the system, they do not want anything to do with politics or the government and they do not go to government offices. They wake up in the morning and only think about what they eat and how they can survive'(I6).

He further added that Sierra Leone resembles almost a police state. People are afraid to demonstrate or argue against the government (I6). This was the case for the majority of youth who participated in this research project. A young barber explained that the government claims freedom of speech but 'your life is gone' when you speak out against them. When discussing the political space of youth and specifically the ability to demonstrate, a young female noted 'even right now I am afraid ... We don't have any rights to talk something, to say anything, everything keep it to yourself, and you cry in your room if you are going through a lot of problems' (I30). Several participants moreover felt that the government portrays youth as having a high potential for Sierra Leone's development but in reality uses them to their own benefit in that youth are given money, alcohol and t-shirts to campaign for a political party (F2). An interviewee from an international agency expressed:

\footnotetext{
'The government to me, they see the youth as a means to acquire what they want' (...) somebody will say they are the future leaders of this country but what has been done to really make them genuine future leaders who will transform this nation (I5)?
}

Notably, the political position of youth in Sierra Leone slightly improved with the first National Youth Policy (2003) drafted by the MOYA and a National Youth Advisory Council. The policy led to the establishment of a governing board: the National Youth Commission 
(NAYCOM), District Youth Councils and a Chiefdom Youth Council to represent youth on all levels.5 While youth are formally represented and recognized in decision-making structures, Sierra Leone's youth programme underlines that most youth are still unaware of their position within these formal structures (Ministry of Youth Affairs 2014). A leading international agency actor also questions:

'These are the structures, these are the frameworks you hear people talk about in radios, in newspapers. Can you tell me where it has been operationalised (I5)?

During FGDs, it was stressed that even while the structures might be improving, it is still difficult for youth to really enter politics and represent a political party (F4, F5). A young lady expressed that she is very small (F1), meaning that she does not have the economic or social capital or status needed to enter politics.

\section{Sierra Leones challenging job market for youth}

During interviews, youth identified an expensive corrupted education system and a scarcity of job opportunities as main challenges in Sierra Leone. A BD programme coordinator argued that many untrained and unqualified youth are a product of the civil war. People growing up during that time 'don't have any idea how to develop a career so that at the end of the day they can take care of themselves' (I9). Another interviewee expressed that youth simply never learned to plan for the future (I13). While this puts emphasis on youth themselves, the programme coordinator underlined that Sierra Leone never had 'a standardized programme that would try to at least directly respond to the effects of the war'(I9). There was no development programme that gave real opportunities to youth or helped them to define their livelihoods (I9). Two prominent government officials and two leading actors at an international donor agency added that a focus on university education persists and there is a 
continuing mismatch between needed labour skills and vocational education, resulting in a poorly qualified working population (I1;I2;I3;I4). Many would agree, that the government in collaboration with international donors failed to establish a more skills focused education system after the war. In 2018 only $0.1 \%$ of the recurrent government budget was allocated to technical/vocational training (Government of Sierra Leone 2017:38). According to a private sector consultant, these developments are further aggravated by a weak private sector that does not provide many jobs (I8).

\section{TVETs in post-conflict Sierra Leone}

During FGDs participants urged the need for youth employment programmes (as part of TVETs) arguing that economic independence would improve their social position (F2). TVET commonly refers to 'vocational training to enhance employability, support the development of knowledges and skills for establishing income generating initiatives, accessing employment opportunities and acquiring relevant communication and networking skills' (Lopes Cardozo, Higgins, and Le Mat 2016, 68) According to Sierra Leone's National Youth Programme 2014-2018 there are still '[c]ontinuing high barriers to accessing formal, technical and vocational education', ‘[p]oor support (...) to young entrepreneurs and youth-oriented enterprises' and a '[1]ack of secure income or employment opportunities resulting in a failure to meet the basic needs of young people: food, water, shelter' (Ministry of Youth Affairs 2014, 13). On the basis of these challenges, Sierra Leone's Education Sector Plan 2018 2020 promotes equal access to youth employment programmes such as TVETs (Government of Sierra Leone 2018). At the same time, it also points out that current TVET programmes differ in quality, fee structures or regional disparities. Especially, the resources and benefits linked to TVET programmes are unequally redistributed as programmes mostly take place in the urban Western areas of Sierra Leone leaving the rural areas behind (Government of Sierra 
Leone 2018, III). Sierra Leones Agenda for Prosperity 2013-2018 further states that youth have to be represented in programme development and that programmes have to provide sustainable innovations and promote social cohesion (Government of Sierra Leone 2013). Against this backdrop we examine a BD programme that has been implemented between 2012-2018 under the national Youth Empowerment and Employment Programme (YEEP) and as part of the country's overall TVET strategies. The YEEP guides Sierra Leone's national youth development processes and aims to unleash youth's potential for national development, since its implementation in 2011.

\section{On the peacebuilding potential of a Business Development programme to improve the situation of Sierra Leone's youth}

The BD programme we use as a case study was implemented by a renowned INGO aiming to facilitate youth employment through micro and small-enterprise development. It built on two objectives: first, the promotion of an entrepreneurial culture by expanding and improving businesses and second, to boost the employment opportunities for heterogenous youth. The BD programme was established in 2012 and originally implemented in five main urban centres: Freetown, Newton, Bo, Makeni and Kenema. Due to funding problems there were only three centres left during the fieldwork period, of which the one in Newton serves as a case study for this paper. Located in the Western Rural District and in close proximity to Freetown, the BD programme was implemented in a periurban area. The programme design underwent significant changes since 2012 due to a combination of cuts in funding and past evaluations. The BD programme design consisted of an eight weeks training built around seven themes covering general business skills including: 'Planning the business activity; Marketing; Customer care; Record Keeping; Savings; Pitching business; and Micro credit 
and finance' (D2). In addition, fieldtrips to factories were also organised to expose youth to new business networks and opportunities which they might never encounter themselves. (D3). The training ended with a Business Plan Competition of which the winners receive grants to start or continue their business. Group participation in this competition was encouraged based on the assumption that more people will benefit from the grants. For example, in 2015, 80 youth (40 female, 40 male) participated in the BD programme of which 76 people divided among 19 partnership groups to take part in the Business Plan Competition. Seven of those partnership groups consisting of 17 females and 12 males received a grant (D6). There were mentors who continued to monitor the grant winners after the training and a board that discussed the feedback of participants every year (D2, I9). With this approach, the BD programme aimed at facilitating self-employment and contributing to relationships of trust by including youth in decision-making processes.

By reverting to our theoretical framework, the 4Rs, we discuss how the programme's de-facto implementation has positively but also negatively affected young people's peacebuilding agency in post-conflict Sierra Leone. We deliberately start our analysis with the recognition of youth's heterogeneity, as it used to be one of the main assets of the programme in its original design in response to some of the root causes of the war in Sierra Leone. We use this as a starting point to showcase how unequal redistribution of grants, caused by external funding cuts, has had a negative effect on recognizing young people's diverse needs but also their representation in the programme as a whole. In this process, the programme not only unintentionally replicated some of the pre-war grievances of youth but also hampered various relationships of trust that are urgently needed to reconcile youth with programme and consequently government officials. 


\section{Recognition of youth's diverse backgrounds and needs}

One of the initial strengths of the programme was that it explicitly aimed at targeting heterogenous youth, thus youth from different ethnicities, religious backgrounds, regions, as well as illiterate and literate and male and female youth. During the early stages of the programme young people's different backgrounds were recognized and acted on through innovative learning methods. For instance, the language of instruction changed depending on participants' backgrounds, pictures were used for illiterate youth or participatory learning methods encouraged knowledge exchange between educated and uneducated participants (I16, I25). A participant who already had a college degree explained that even though the new knowledge he gained through the programme was minimal:

\footnotetext{
'it was a good experience because you can also learn from them [uneducated], I think it helped them as well because of our interaction. Some of us were in a better position to help them understand certain things so it is a very good interaction'(I25).
}

In recognizing the socially excluded position of youth, the programme brought heterogenous youth together to share experiences and learn from each other, thereby promoting social cohesion, inclusion and equal opportunities. Unfortunately, over the years, the programme's admission process changed radically, due to severe shortage in funds, which increasingly excluded marginalised youth. These funding cuts have led to restrictions in redistributing resources within the programme, which consequently affected young people's representation in regard to heterogeneity but also in decision making processes about the programme's design. 


\section{From mission-driven to donor-driven: issues of redistribution and representation}

Between 2015 and 2017, Official Development Assistance (ODA) to Sierra Leone shrunk by 43\% (from 946.3 USD million to 537.6 USD million).6 These cuts in development assistance, combined with a shift of donor's attention to mitigate the Ebola crisis, did not leave the BD programme unaffected, including many other initiatives for marginalised youth. Because of this sudden shortage of funds, one of the programme's biggest implementation challenges soon appeared to be unequal redistribution of resources, unequal access to the programme and the inability to listen to, incorporate and represent young people's feedback on implementation challenges. Yet the number of youth that applied for the programme exceeded the BD programme's capacity every year and many youth that wished to study business development were frequently led down due to a lack of space and capacities. In 2015, in total 160 youth applied but only half could participate in the training. The implementing agency did its best to meet the demand. For instance, in 2015, the programme originally had place for 60 youth but accepted 20 more (I9.1;D2).

The continuous shortening of funds made it also more difficult for the implementing agency to listen to and act on youth's needs (I9.1). Over time, this has led to a programme design that is 'more donor-driven than mission-driven' and not based on youth's everyday challenges and heterogenous backgrounds (I11). For example, youth complained about the location of the training centre, arguing that it is too far from remote rural communities, difficult to reach for those who cannot afford transportation thereby exacerbating existing urban-rural divides (F5). To cite one interviewee:

\footnotetext{
'Some [participants] are really poor, they cannot afford that [transport]. In fact it is something that we have always included, I think it is only this year that we did not include it in our report. It's something we have been really really pushing to the donor, if we really want to get to more people more deprived people we have to like move a step ahead, transportation, basic transportation' (I9).
} 
In addition, the selection process of participants was gradually outsourced to a Business Registration Union (BRU). At first sight this may seem as being helpful as the BRU 'coordinates the affairs of businesses in Sierra Leone' and provides mentors who guide participants after the programme is completed (I9.1). But at a closer look, it became evident that the BRU employees mostly select BRU members who are paying monthly fees to the BRU, to be eligible to participate in a BD programme (I18; I19). This led to a different and more costly admission process for youth and had severe implications for the programme's initial intention to acknowledge heterogeneity of youth as youth who cannot afford to pay BRU fees are already excluded by default. Besides, an employee of the BRU noted that new BD participants should 'at least know how to read and write' going against the programmes intentions to also include illiterate participants (I19). The BD programme coordinator later explained that the collaboration with the BRU was still in its early stages and that this was an issue that could easily be corrected and dealt with (I9.2). It still exemplifies the difficulties and unintended consequences that arise in regard to redistribution of resources and young people's uneven representation when parts of a programme are being outsourced.

\section{Unequal redistribution of grants}

Those who were able to participate in and complete the programme, further struggled with access to resources in that only a few selected participants received grants to further their business plans after they completed the programme. In order to win the Business Plan Competition, youth have to participate in interviews, pitch their business plan and physically show their business to the implementing agency (I9.2). Originally, the BD programme pilot in 2012 gave out loans comparable to micro-finance schemes. However, when youth reported that they would not be able to pay back the loans, this scheme quickly changed into grants (I9; 
F5), which were significantly reduced each year. This resulted into favouring existing businesses over financing new businesses (I9.1), thereby leaving the most marginalised and unemployed youth behind. An additional programme change included to provide grants to groups instead of individuals with the thought that more participants would benefit from the little means available (I9). In practice, this led to less financial means for youth to either improve or open up their businesses (I28, I29), as explained by the BD programme manager as follows:

'our flagship businesses that we can really point at are people who never had businesses before. They were given money but the only situation is they were given much, I mean enough money somehow compared to how much we are given out now' (I9.1).

One of these former flagship businesses is a bakery run by a young male who received 8.3 million Leones (930 USD) in 2014 (I26).7 The bakery is not only very successful but also employs other youth, in line with the main objectives of the BD programme. Youth groups who won the business plan competition three years later, in 2017, only received 3 to 5 million Leones (335 - 560 USD) per group (D1), making it really difficult for them to start successful businesses on their own. One female who received a 3 million grant in 2017 as part of a group consisting of three noted that the grant was too small to start a new business, hence they decided to divide the money between themselves (I28).

Funding cuts further resulted in less monitoring and mentoring of new businesses. While the baker's flagship business benefited from a year-long bi-weekly monitoring, these efforts were significantly reduced after 2014. According to the programme coordinator there are no longer any resources available for long-term follow-ups (I9). Instead, mentorship is unequally redistributed, has become more of a personal favour and is in part outsourced to the BRU. 
Interviewees who participated in the programme in 2017 reported very different experiences in regard to monitoring and mentoring. A tailor noted that the implementing agency followedup on several occasions (I25), in contrast to a construction market owner who said that he neither had a mentor nor received follow-up visits or any help to formally register his business (I27). Participants who did not get a grant would hardly receive mentoring or any help with registering a bank account or their businesses (I9;I9.1;I9.2).

Most of the participants frustrations stemmed from a lack of transparency during the grantgiving process. Participants that were interviewed did not understand why they lost the competition. 'We pitched everything: no result. They say: go we will call you and we were never called, no result' (F2). At the same time, youth also critiqued that all grant winners resided nearby the training centre (F5). Consequently, some participants linked losing the competition to their lack of sababu, implying that grants were given on the sheer basis of connectocracy (F5). While these claims were neither substantiated nor denied by trustworthy evidence, it reflects the everyday experiences of youth in Sierra Leone, characterized by clientelism, corruption and poverty. The lack of transparency in allocating grants, combined with mentorship based on personal favourism made youth question the fairness of the grantgiving process and BD programme as a whole. This exemplifies how the resurfacing of some of the root causes of Sierra Leone's conflict during the implementation of small scheme development programmes, can have a far reaching effect on young people's various relationships of trust.

Every participant did however obtain a certificate, which was generally valued among youth (F1), but did not prove to be helpful in gaining employment or funding to set up a business. As noted by one interviewee: 
'there is no big business institution, no supermarket maybe there is other countries around with big supermarkets, you go there with your certificate then you seek for employment but in Sierra Leone no big business institution so where can I go with my certificate and seek for employment? '(F3).

This not only raises questions about the usefulness of certificates but also about the impact of severely underfunded and under-capacitated BD programmes more generally and their potential to boost employment opportunities for youth in an extremely difficult economic context and post-conflict environment.

\section{Reconciliation: regaining young people's trust}

As the previous sections have shown, for the majority of its beneficiaries, the BD programme did not significantly address historically rooted tensions of social inequality, the lack of educational and job opportunities and power structures based on neopatrimonialism. Processes of selecting grant holders further resulted in a feeling among youth that without a sababu, pre- and immediate post-war grievances as well as favouritism have still not disappeared in Sierra Leone. According to our interviewees, the importance of a sababu and connectocracy continues after education is completed. Talking about the difficulties of finding employment, a young male explained:

\footnotetext{
'I can apply, you can apply. You are qualified, I am not qualified and when you go for an interview they will ask you who sent you, they will never ask you for your qualifications. ... so that is frustrating people' (F2).
}

Also the exclusion of the most marginalised and vulnerable youth from the BD programme did little to address pre- and post-war conditions of youth. Scholars who studied the war in Sierra Leone agree that the RUF's (Revolutionary United Front) motives were deeply rooted 
in decade-long socio-economic grievances and political oppression (Keen, 2005; Peters, 2011). Seen from this perspective, the programme's financial and capacity constraints and therefore inability (despite its good intentions) to include and respond to youth voices in important decision-making processes not only increased youth's social, economic and political exclusion but further impedes relationships of trust, if not trust in the wider development and peacebuilding process of the country as a whole. This is clearly a missed opportunity by aid agencies and donors, as BD programmes (and TVET strategies at large), could have the potential to respond to underlying political, social and economic tensions and consequently contribute to a country's peacebuilding process at large. In the specific case of Sierra Leone, this further extends to re-stablishing trust between youth and the government, which was expressed by a young male as follows:

'I do not trust them [the government] because I am taking care of myself since young, the government does not know about me'(I24).

It is worth noting that a government agency, did in fact support the programme through the provision of training centres. This government agency was however not able to provide further funding in response to feedback from the implementing agency about continuous grievances, as explained by one of the employees of the programme:

\footnotetext{
'For now for instance the BD programme is $100 \%$ financially supported by [reference to international development organisation], they are just like providing the centres where we operate. They are not giving us any money to operate, because they don't have. Genuinely I told you we are working in close relationship with them. They will have the intention. The commissioner is determined (...) they say they want to do more, they really want to move a step but they don't have the resources' (I.9).
} 
If Julius Maada Bio's new presidency truly lives up to its promise to expand the education sector by allocating $21 \%$ of the total public spending to education, extending that support to ongoing BD programmes more explicitly could be one of the many thus far missed opportunities to regain young people's trust in the country's peacebuilding and development process.

Apart from involving the government, the implementing agency did also try to promote social cohesion and trust among youth through a postgraduate network. The network was initiated by youth who participated in programmes of (or are linked to) the implementing agency. The idea behind the network is to connect youth to be of each other's help, exchange opinions or share job opportunities. It received funding from the implementing agency to 'formally register the group with the local council and the National Youth Commission'(D2). Officially registering the postgraduate network gave youth the feeling to be more visible to the government and fostered social cohesion among youth and the wider community, as explained by the programme manager:

\footnotetext{
'We create those opportunities for them, for instance when the mudslide came, what we did before the mudslide: Ebola. The implementing agency is not working on emergencies but we have been working more on community mobilisation before. Having that experience we were like the lead agency in social mobilisation so what we did was come up with a clear approach: the community led action approach were we ask the community to develop the action plans and take lead roles in implementing those plans. What they think they could do to end Ebola and we were like across the country we were able to mobilize over 1000 of young people to lead and support in that intervention.' (I.11).
}

Youth we interviewed about the nature and effectiveness of the network gave rather mixed responses, however. For instance, the regional postgraduate networks chairperson is excluded 
from the postgraduate network as she is not able to pay the monthly fees (I15). During FGDs it was further noted that many youth are not aware of or do not participate in the network and described it as dormant (F5).

\section{Conclusion}

Our analysis of young people's responses through the lens of the 4R framework brought to light that in the scope of a small scale BD programme, current grievances experienced by youth are still similar to pre-war conditions in Sierra Leone, hampering the peacebuilding and wider reconciliation process of the country. From a broader perspective, the legacies of the war fortified severe poverty, corruption, lack of opportunities, and extreme vulnerability to internal and external environmental, economic and political shocks. This is combined with a general dissatisfaction among youth whose opportunities largely depend on neopatrimonial power structures and consequently a general mistrust in the government. The situation for youth is further aggravated by the unpredictability of economies in fragile settings, a conflictaffected and weak private sector and the wider political economy context in general. As argued elsewhere, local implementing agencies, especially CSOs or INGOs, are limited in addressing the everyday needs of youth as their agenda setting is frequently externally driven and closely tied to funding allocations (omitted reference). This results in generic programmes and unsatisfied expectations that could further existing social and economic grievances if not lead to renewed conflict.

Against this backdrop, we want to conclude by reverting to our main question, namely: How did a BD programme (in alignment with Sierra Leone's overall TVET strategy) shape the agency of heterogenous youth in the peacebuilding process of post-conflict Sierra Leone? 
We found that despite the BD programme's good intentions and its initial ability to foster social cohesion and reconcile heterogenous youth through an inclusive programme design, the programme struggled to counter social inequality, overcome the general lack of employment opportunities and avoid neopatrimonialism. In part, this was caused by external structures that enforced changes in programme design and implementation. The sudden decrease in donor funding affected the redistribution process of the BD programme, thereby hampering young people's representation and compromising the recognition of their diverse backgrounds and needs. This not only undermined the programme's initial mission of reaching out to heterogenous youth but also youth's peacebuilding agency at large. Although coordinators did their best to recognize participants' specific needs and listen to their viewpoints and concerns, youth had little power to influence the redistribution of recourses or the programme's strategies and design to counter their everyday struggles and experiences (see also: Lopes Cardozo, Higgins, and Le Mat 2016, 68). The 4Rs framework has helped us to reveal how the resurfacing of pre-war conditions in terms of unequal redistribution and a lack of representation and recognition, can hamper young people's trust in programme and also government officials, impeding ongoing efforts of reconciliation. In dismantling processes of redistribution, recognition, representation and reconciliation we were further able to understand how the BD programme unintentionally altered social and political everyday life for youth in Sierra Leone. A fragile setting is often marked by underlying social tensions and the 4Rs framework revealed how educational programmes with a focus on livelihoods enhancement influence such tensions in the broader peacebuilding context of post-conflict societies. At the same time, we are aware that by making use of the 4Rs framework we assessed this phenomeon from a western epistemological approach and stance. We believe that more research and work is urgently needed in the future to embed such an analysis in African scholarship, social justice frameworks and philosophical thought (see for instance: 
Lajul 2014), to support ongoing attempts to decolonize research and debates around 'development'.

To conclude, in its current form, the BD programme was not attuned to the local job market and did not sufficiently involve the private sector or the government to create realistic income generating activities for youth. We therefore recommend transparent and fair grant allocation procedures in TVET programmes. This would not only counter persisting forms of clientelism but also regain young people's trust in the 'system'. Overall, our study implies that TVET strategies in any post-conflict context need to look beyond narrow technical and economic problem framing in order to utilize youth's potential for peacebuilding. A sole focus on business (or any other) skills appears to be too narrow and technical to really address historical, political, economic and social tensions that shape the everyday reality of youth in conflict affected areas. While global peacebuilding and development rhetoric recognizes that youth participation is required to develop suitable programmes for local realities, this rhetoric needs to be translated into practice by increasing donor funding, commitment, local capacities and a general political will to truly improve the situation of youth in conflict affected environments. 


\section{Bibliography}

African Union. 2006. African youth charter. Addis Ababa: African Union.

Ashby, C. 2011. Whose "Voice" is it Anyway?: Giving Voice and Qualitative Research Involving Individuals that Type to Communicate. Disability Studies Quarterly 31(4).

Batmanglich, S., and L. Enria. 2014. "Reframing Youth Employment Programming in Liberia and Sierra Leone," . London: International Alert.

Bennell, P., Harding, J., and Rogers-Wright, S. 2004. PRSP education sector review. Freetown: British Council Sierra Leone.

Cubitt, P. C. 2011. "Employment in Sierra Leone: What Happened to Post-Conflict Job Creation?" African Security Review 20 (1): 2-14. doi:10.1080/10246029.2011.561007.

Denney, L. 2011. "Reducing Poverty with Teargas and Batons: The Security-Development Nexus in Sierra Leone.” African Affairs 110 (439): 275-94. doi:10.1093/afraf/adr004.

Dunne, A., D. Ulicna, I. Murphy, and M. Golubeva. 2014. "Working with Young People: The Value of Youth Work in the European Union,” 209. doi:10.2766/72658.

Enria, L. 2015. "Love and Betrayal: The Political Economy of Youth Violence in Post-War Sierra Leone.” Journal of Modern African Studies 53 (4): 637-60. doi:10.1017/S0022278X15000762.

Fraser, N. 1995. "From Redistribution to Recognition? Dilemmas of Justice in a 'PostSocialist' Age." New Left Review 212: 68-93.

Fraser, N. 2005. "Reframing Justice in a Globalizing World.” New Left Review, no. $36: 69-88$.

Galtung, J. 1976. Peace, War and Defense. Leiden: BRILL Publishers. Government of Sierra Leone. 2013. "The Agenda for Prosperity. Road to Middle Income Countries. Sierra Leone‘s Third Generation Poverty Reduction Strategy Paper 2013 2018," Strategy Paper, Sierra Leone. 
Government of Sierra Leone. 2017. Government Budget and Statement of Economic Financial Policies: For the Financial Year 2018, Theme: "STRENGTHENING RESILIENCE FOR INCLUSIVE GROWTH”. Accessed August 11th 2019. http://www.parliament.gov.sl/dnn5/Portals/0/2014\%20DOCUMENT/BUDGET/2018\%20BUD GET\%20SPEECH,\%2OPROFILES\%20AND\%20FISCAL\%20STRATEGY\%20STATEMENT.pdf

Government of Sierra Leone. 2018. Education Sector Plan 2018-2020. Education Sector Plan, Ministry of Education, Science and Technology, Sierra Leone.

Hanlon, J. 2005. "Is the International Community Helping to Recreate the Preconditions for War in Sierra Leone?" Round Table 94 (381): 459-72. doi:10.1080/00358530500243641.

Harris, D. 2014. Sierra Leone: A political history. USA: Oxford University Press.

Higgins, S., and M. Novelli. 2020. "Rethinking Peace Education: A Cultural Political Economy Approach." Comparative Education Review 64 (1): 1-20. doi:10.1086/706759. Jalloh, A. 2019. "Sierra Leone develops new national technical vocational training policy." The Sierra Leone Telegraph, 10 April 2019. https://www.thesierraleonetelegraph.com/sierra-leone-develops-new-national-technicalvocational-training-policy/

Kalangba, E. 2018. "Sierra Leone: The Julius Maada Bio rresidency and the people's expectation-free education.” Concord Times, April 10. http://slconcordtimes.com/kalangba-echo-5/

Keen, D. 2005. Conflict and collusion in Sierra Leone. Melton: James Currey (imprint of Boydell \& Brewer Ltd.).

Keili A. 2018. Sierra Leone's finance minister's balancing act on a trapeze - the 2019 budget. The Sierra Leone Telegraph, 7 November 2018. 
https://www.thesierraleonetelegraph.com/sierra-leones-finance-ministers-balancing-act-ona-trapeze-the-2019-budget/

Kemper, Y. 2005. Youth in war-to-peace transitions: Approaches by international organisations. Berlin: Berhof Research Center.

Kincheloe, J. L., and McLaren, P. 2000. Rethinking critical theory and qualitative research. In N. Denzin \& Y. Lincoln (Eds.), Handbook of Qualitative Research (pp. 279-314). Thousand Oaks, CA: Sage Publications, Inc.

Lajul, W. 2014. African philosophy: critical dimensions. Uganda: Fountain Publishers. Lederach, J. P. 1995. Preparing for Peace: Conflict Transformation Across Cultures. Syracuse University Press.

Lederach, J. P. 1997. Building Peace: Sustainable Reconciliation in Divided Societies. Washington: United States Institute of Peace Press.

Lopes Cardozo, M., S. Higgins, and M. Le Mat. 2016. "Youth Agency and Peacebuilding An Analysis of the Role of Formal and Non-Formal Education: Synthesis Report on Findings from Myanmar, Pakistan, South Africa and Uganda." Research Consortium Education and Peacebuilding Amsterdam: University of Amsterdam.

Lopes Cardozo, M. and Scotto, G. 2017. Youth, Peacebuilding, and the Role of Education. New York: The Inter-Agency Network for Education in Emergencies.

McEvoy-Levy, S. 2006. Troublemakers or peacemakers?: Youth and post-accord peace building. Inidana: University of Notre Dame Pr.

Ministry of Youth Affairs. 2014. “A Blue Print for Youth Development 2014-2018 Sierra Leone's National Youth Programme." UNDP, Sierra Leone.

Mitton, K. 2015. Rebels in a rotten state: understanding atrocity in the Sierra Leone civil war. Oxford: Oxford University Press.

Nishimuko, M. 2007. Problems behind education for all (EFA): The case of Sierra 
Leone. Educate 7(2): 19-29.

Nishimuko, M. 2009. "The Role of Non-Governmental Organisations and Faith-Based Organisations in Achieving Education for All: The Case of Sierra Leone." Compare 39 (2): 281-95. doi:10.1080/03057920902750525.

Novelli, M. 2011. The role of education in peacebuilding. Case study: Sierra Leone. New York: UNICEF.

Novelli, M. and S. Higgins. 2017. "The Violence of Peace and the Role of Education: Insights from Sierra Leone." Compare 47 (1). Routledge: 32-45. doi:10.1080/03057925.2015.1119650.

Novelli, M., M. Lopes Cardozo, and A. Smith. 2017. “The 4RS Framework: Analyzing Education's Contribution to Sustainable Peacebuilding with Social Justice in ConflictAffected Contexts." Journal on Education in Emergencies 3 (1): 14-43. http://s3.amazonaws.com/inee-assets/resources/JEiE_V3_N1_4Rs_Framework.pdf.

Oketch, M. O. 2007. "To Vocationalise or Not to Vocationalise? Perspectives on Current Trends and Issues in Technical and Vocational Education and Training (TVET) in Africa.” International Journal of Educational Development 27 (2): 220-34. doi:10.1016/j.ijedudev.2006.07.004.

Paris, R. 2004. At war's end: building peace after civil conflict. Cambridge: Cambridge University Press.

Peters, K. 2011. War and the crisis of youth in Sierra Leone. Cambridge: Cambridge University Press.

Pruitt, Lesley. 2020. "Rethinking Youth Bulge Theory in Policy and Scholarship: Incorporating Critical Gender Analysis.” International Affairs 96 (3): 711-28. doi:10.1093/ia/iiaa012. 
Sayed, Y., Badroodien, A., McDonald, Z., Salmon, T., Balie, L., De Kock, T., Hanaya, A.,

Skirhotte-Kriel, W., Gaston, J. and Foulds, K. 2016. Teachers and youth as agents of social

cohesion in South Africa, Cape Town: Centre for International Teacher Education.

Sierra Leone Truth and Reconciliation Commission. 2004. Witness to Truth; Report of the

Sierra Leone Truth and Reconciliation Commission. volume 3, Chapter 3, Accra:

SLTRC.

Smith Ellison, C. 2014. "The Role of Education in Peacebuilding: An Analysis of Five

Change Theories in Sierra Leone." Compare 44 (2): 186-207.

doi:10.1080/03057925.2012.734138.

World Bank. 2017. World Development Report 2018: Learning to Realize Education's

Promise. doi:10.1596/978-1-4648-1096-1_ov.

\section{Notes}

1United Nations Development Programme Sierra Leone, available at:

http://www.sl.undp.org/content/sierraleone/en/home/countryinfo.html (accessed on 28 April 2019).

2 We do not disclose the name of the implementing agency to protect the privacy of the participants.

3 UN Security Council Resolution on Youth, Peace and Security (2250). Available at:

https://www.un.org/development/desa/youth/international-youth-day-2017/resources-on-youth-peace-andsecurity.html (Accessed on 1 September 2019); See also: Lopes Cardozo and Scotto (2017) for a recent discussion of the UN security resolution on youth, peace and security (2250).

4 United Nations Development Programme Sierra Leone. Available at:

http://www.sl.undp.org/content/sierraleone/en/home/countryinfo.html (accessed on 28 August 2019).

5 See: http://www.youthpolicy.org/factsheets/country/sierra-leone (accessed 23 August 2019).

6 OECD Aid at a Glance. Available at:

https://public.tableau.com/views/OECDDACAidataglancebyrecipient_new/Recipients?:embed=y\&:display_cou nt=yes \&: show Tabs=y\&:toolbar=no? \&: showVizHome=no (accessed 7 July 2019).

71 million Leones equals a bit more than 100 Euros. 